\title{
STRES DAN SIMPTOM ONYCHOPHAGIA DALAM KALANGAN KANAK-KANAK PRASEKOLAH ORANG ASLI
}

\author{
Stress and Onychophagia Symptoms Amongst Orang Asli Pre-School Children
}

\author{
Nor Aimi Hj. Harun ${ }^{1}$, Fauziah Md. Jaafar ${ }^{2}$ \\ Pusat Pengajian Pendidikan dan Bahasa Moden \\ Universiti Utara Malaysia, Sintok, Kedah, Malaysia. \\ aimyallyia@yahoo.com.my ${ }^{1}$,mjfauziah@uum.edu.my²
}

\begin{abstract}
ABSTRAK
Golongan kanak-kanak dan remaja turut berhadapan dengan pengaruh stres dan ianya merupakan ancaman yang serius dalam kalangan murid sekolah. Kajian kes kualitatif ini dilaksanakan untuk mengenal pasti kewujudan dan simptom stres dalam kalangan murid prasekolah Orang Asli. Sampel kajian melibatkan seorang kanak-kanak prasekolah orang asli. Instrumen pengumpulan data yang digunakan dalam kajian ini adalah protokol temu bual, senarai semak, pemerhatian dan dokumen. Data transkrip dianalisis dengan menggunakan perisian Nvivo 0.8. Dapatan menunjukkan subjek kajian mengalami stres di tahap skor75 mata berdasarkan Instrumen Pengukuran Stres: Child and Adolescent Survey of Experiences (CASE). Simptom stres yang ditunjukkan oleh subjek kajian adalah masalah Onychophagia. Simptom Onychophagia merupakan habit menggigit kuku dan ia merupakan masalah psiko-emosi (psycho emotional) berkait dengan stres. Kanak-kanak tersebut melakukan tindakan menggigit kuku sewaktu berada dalam tertekan dan tindakan tersebut memberi kesan kepada kesihatan anggota tangan dan amat mempengaruhi perkembangan fisiologi, psikologi dan tingkah laku. Kajian ini memberi implikasi kepada guru-guru prasekolah, ibu bapa dan stakeholder secara proaktif dan kolektif bagi membangunkan strategi daya tindak (coping skills) untuk kanak-kanak orang asli yang mengalami stres.
\end{abstract}

Kata Kunci: Stres, prasekolah, orang asli.

\begin{abstract}
Children and adolescents are also faced with the effects of stress and are a serious threat among schoolchildren. This qualitative case study was conducted to identify the existence and stress of stress among Aboriginal preschools. The sample of the study involved a native child pre-schooler. Data collection instruments used in this study were interview protocols, checklists, observations and documents. Transcript data was analysed using Nvivo software 0.8. The findings showed that subjects were subjected to stress at the score of 75 points based on Stress Measurement Instrument: Child and Adolescent Survey of Experiences (CASE). The stress symptoms indicated by the subject were Onychophagia. The Onychophagia Syndrome is a nail bite habit and it is a psycho-emotional problem associated with stress. The kid performed nail biting action while under stress and the action affected the health of the hands and greatly influenced the development of physiology, psychology and behaviour. This study implies proactively and collectively preschool teachers, parents and stakeholders to develop coping skills for stressed indigenous children.
\end{abstract}

Keywords: Stress, preschool, indigenous

\section{PENDAHULUAN}

Masalah kesihatan mental berlaku kesan dari tekanan (stres) psikologikal terhadap sistem ketahanan badan (immune system). Stres bukan sahaja berlaku dalam kalangan dewasa, malah 
golongan kanak-kanak dan remaja turut mengalami ancaman pengaruh stres (Videbeck, 2011). Berdasarkan kajian Morbiditi dan Kesihatan Kebangsaan-NHMS, (2006), yang bermula dari tahun 1996 hingga 2006 telah menunjukkan kadar peningkatan stres yang tinggi dari sekitar 13 peratus kepada 20.3 peratus dalam kalangan kanak-kanak dan remaja berusia antara 5 hingga 15 tahun. Ini bermakna terdapat peningkatan sekitar 7.3 peratus dalam tempoh sepuluh tahun (NHMS -Laporan Kajian Morbiditi dan Kesihatan Kebangsaan, 2006). Masalah tersebut terus membimbangkan berdasarkan laporan terkini Kajian Morbiditi dan Kesihatan Kebangsaan, (2016), yang telah mengesan wabak morbiditi psikiatri melibatkan masalah kesihatan mental bagi kanak-kanak berusia dalam lingkungan 5 hingga 16 tahun telah mencecah ke paras 600,000 orang. Data tersebut selari dengan dapatan kajian projek rintis Program Minda Sihat Menangani Stres yang dijalankan oleh Kementerian Pendidikan Malaysia dengan kerjasama Kementerian Kesihatan Malaysia (KPM, 2011) terhadap 6,540 orang murid telah mendapati sebanyak 17.1 peratus mengalami tanda-tanda keresahan yang teruk, 5.2 peratus mengalami kemurungan yang teruk dan 4.8 peratus murid didapati mengalami masalah stres yang teruk, manakala 36 peratus terpaksa mengikuti program intervensi latihan Kemahiran Daya Tindak stres (Utusan Malaysia, 2011), (KPM, 2011). Ini bermakna seramai 1,118 orang murid mengalami tanda-tanda keresahan yang teruk dan seramai 314 orang murid dari 6,540 mengalami masalah stres yang teruk. Statistik terbaru berdasarkan surat siaran 'Garis Panduan Perlaksanaan Program Minda Sihat- Menangani Tekanan Emosi (Stres) Dalam Kalangan Murid Di Sekolah 2014', menunjukkan masalah kesihatan mental dalam kalangan kanak-kanak dan remaja Malaysia telah meningkat kepada 20 peratus (Kementerian Pendidikan Malaysia, 2014).

Data terbaru Kajian Kesihatan dan Morbiditi Kebangsaan (2015) mendedahkan bahawa masalah kesihatan mental dalam kalangan pelajar semakin meningkat berdasarkan nisbah 1:10 pada tahun 2011, kepada 1:5 orang dalam tahun 2016 (Lee Lam Thye, 2018). Di Malaysia, maklumat mengenai masalah kesihatan mental stres dalam kalangan kanak-kanak prasekolah orang asli masih belum meluas. Kajian terhampir oleh beberapa penyelidik tempatan seperti Norly (2010), Nor (2011), Puvarasi (2013) dan Fariza (2005) hanya berfokus kepada masalah stres di kawasan urban dan pinggir urban sahaja tanpa menoleh ke kawasan pendalaman orang asli.

Menurut Sandberg (2012), masalah kesihatan mental ini perlu diberi perhatian kerana kesan stres boleh menyebabkan gangguan kepada perkembangan sosial dan kognitif kanakkanak. Marcelo dan Yates (2014) turut mengakui bahawa golongan kanak-kanak turut berdepan dengan masalah kesihatan mental stres. Mereka menggesa agar masalah kesihatan mental stres dalam kalangan kanak-kanak harus ditangani segera.

\section{PERNYATAAN MASALAH}

Menurut Nik Nasaruddin (2015), murid-murid orang asli turut mengalami masalah psikologi seperti trauma dan stres merujuk kepada isu kematian 5 dari 7 orang murid orang asli di SK. Pos Tohoi pada tahun 2015. Insiden berpunca dari perasaan takut dihukum kerana melanggar peraturan asrama dengan pergi mandi di sungai berhampiran sekolah (Mazlan, 2015). Gangguan aspek psikologi ini membuktikan bahawa kelompok kanak-kanak orang asli turut mengalami masalah kesihatan mental stres. Namun wujud kelompang dan kesukaran menemui hasil penyelidikan dan perbincangan ilmiah berkaitan kesihatan mental stres dalam kalangan kanak-kanak prasekolah orang asli. Kelompangan tersebut membuktikan kajian stres khusus yang melibatkan kanak-kanak prasekolah orang asli di negara ini masih belum diterokai 
sepenuhnya. Keadaan ini harus dilihat secara kritikal kerana kelompok kanak-kanak minoriti ini bukan sahaja berhadapan dengan konflik sosio ekonomi, tetapi juga isu psikologi (Nur Bahiyah. Maryati, Azman dan Mohd Najib, 2013)

Keadaan ini berbeza di luar negara di mana kajian masalah kesihatan mental stres di peringkat kanak-kanak prasekolah orang asli telah begitu berkembang dan meluas dalam pelbagai skop. Terdapat banyak kajian luar negara yang membuktikan wujudnya masalah kesihatan mental stres dalam kalangan kanak-kanak aboriginal (Carter, 2007), (Deborah, 2013), (Paradise, 2004), (Purdie dan Buckley, 2010), McRae (2008), Bourke (2000), (Armstrong dan Buckley, 2011). Kupasan kajian Purdie dan Buckley (2010) telah mendedahkan bahawa masalah kelemahan dan kegagalan guru 'berinteraksi' dengan golongan ini sewaktu pengajaran dan pembelajaran telah menimbulkan stres dalam kalangan kanakkanak orang asli (aboriginal) di Australia.

Justeru, keperluan kajian stres dalam kalangan kanak-kanak prasekolah orang asli dilihat begitu mendesak dan perlu ditadbirkan segera bagi memahami fenomena stres dalam kalangan kanak-kanak prasekolah orang asli.

\section{OBJEKTIF KAJIAN}

Objektif kajian ini adalah untuk mengesan kewujudan stres dan simptom stres yang ditunjukkan oleh kanak-kanak prasekolah orang asli.

\section{METODOLOGI KAJIAN}

Kajian kualitatif kajian kes digunakan bertujuan untuk meneroka fenomena stres secara terperinci dan mendalam yang berlaku dalam kalangan kanak-kanak prasekolah orang asli. Pemilihan reka bentuk kajian kes bertujuan untuk memahami sesuatu isu yang kompleks dalam persekitaran semula jadi. Pemilihan reka bentuk ini bertepatan dengan saranan Clarke dan Creswell (2015), Chua Yan Piaw (2006) dan Fraenkel dan Wallen (2000) yang menegaskan penggunaan pendekatan kualitatif dapat melihat fenomena sesuatu isu dari sudut yang berbeza dan pelbagai. Instrumen pengumpulan data yang digunakan dalam kajian ini adalah protokol temu bual, senarai semak pemerhatian dan analisis dokumen. Temu bual bebas dan separa bebas telah diaplikasikan dalam kajian berdasarkan keperluan dan objektif yang telah ditentukan. Data dari dokumen digunakan dalam kajian ini adalah dari sumber yang sahih dan mempunyai kesahan tinggi. Penyelidik juga memastikan dokumen yang diperoleh adalah tepat dan tidak bias. Kaedah pemerhatian yang digunakan bertujuan untuk melihat tema-tema penting yang berlaku dalam persekitaran semula jadi. Penggunaan kaedah pemerhatian amat penting dan bermakna apabila sumber data bukan dalam bentuk vokal atau dokumen. Penyelidik menggunakan borang pemerhatian bagi mencatat data penting dalam suatu peristiwa semula jadi.

Kesemua data-data yang diperoleh dari instrumen temu bual, rujukan dokumen dan pemerhatian telah dianalisis dan di kod berdasarkan tema-tema bermakna yang ditemui. Proses analisis melibatkan tiga tahap penting melibatkan transkripsi, analisis dan identifikasi tema. Braun dan Clarke (2013), Cohen, Manion, Morrison (2007), O’Leary (2004), Creswell (2005), Patton $(1990,2002)$ dan Clark dan Creswell (2015) menyarankan penggunaan instrumen temu bual, pemerhatian dan analisis dokumen dalam kajian kualitatif kerana instrumen tersebut 
dapat membantu penyelidik memperoleh data dari pelbagai sudut sehingga ke tahap tepu (saturation).

Bagi menganalisis data-data yang diperoleh dari instrumen pengumpulan data seperti temu bual, pemerhatian dan dokumen, penyelidik telah menggunakan program Nvivo 0.8. Penggunaan perisian Nvivo 0.8 dapat membantu penyelidik dalam pelbagai aspek seperti menyimpan, merekod data dan membuat sistem klasifikasi. Selain itu, penggunaan perisian tersebut dapat membentuk kod-kod dikehendaki dan membuat carian data-data semula dengan pantas. Menurut Creswell (2005), penggunaan Nvivo 0.8 dalam sesuatu kajian dapat memberikan kejituan dalam menganalisis data dari aspek penyimpanan dan menyusun data serta melabel.

Sampel kajian yang dipilih dalam kajian ini adalah berdasarkan sampel bertujuan (purposeful sampling) melibatkan seorang kanak-kanak prasekolah orang asli berusia enam tahun. Justifikasi pemilihan sampel dibuat atas alasan praktikal berdasarkan kepada peratusan kehadiran yang paling rendah melalui rujukan Rekod Kehadiran Murid bagi penggal pertama tahun persekolahan semasa. Faktor kedua pemilihan sampel kajian adalah berdasarkan penetapan had umur pemula enam tahun yang disyaratkan dalam instrumen pengukuran stres Child Adolescent Survey of Experiences (CASE) (Charities, 2016). Selain itu, tahap kebolehan akses kepada lokasi dan budaya juga menjadi faktor penentu kepada pensampelan bertujuan (purposeful sampling) dalam kajian ini. Selain itu, kajian ini juga melibatkan seorang guru prasekolah, seorang Pembantu Murid (PM) dan kedua ibu bapa sebagai informan. Justifikasi pemilihan sampel yang kecil ini bersesuaian dengan sifat kajian kes yang memilih individu atau lokasi yang telah dikenal pasti secara khusus dan mendalam untuk memahami suatu fenomena (Gay dan Airasian,2003), (Creswell, 2005).

Selain itu, lokasi kajian dan keunikan persekitaran sampel juga menjadi pertimbangan dalam pensampelan bertujuan (purposeful sampling). Lokasi kajian merupakan sebuah sekolah rendah orang asli di pendalaman dan telah terpilih sebagai sekolah Projek Rintis Abad 21 dan merupakan prasekolah tunggal projek rintis program 'PEERS' bagi sekolah orang asli Negeri Perak. Lokasi kajian merupakan sekolah berpusat bagi 12 penempatan orang asli yang berselerakan dalam jangkau 19 kilometer ke pendalaman.

Oleh itu, sampel dan lokasi yang dipilih dalam kajian ini adalah bertepatan dengan saranan Chua Yan Piaw (2006), Braun dan Clarke (2013) yang menyarankan asas kepada pemilihan lokasi dan sampel kajian adalah berdasarkan kepentingan pensampelan bagi kes spesifik terhadap individu atau kumpulan yang unik.

\section{Instrumen Pengukuran Stres: Child and Adolescent Survey of Experiences (CASE)}

Bagi mengesan dan mengukur tahap stres berdasarkan keperluan kajian, penyelidik telah menggunakan alat ukur stres Instrument Child and Adolescent Survey of Experiences (CASE). Instrumen CASE telah dibangunkan oleh Centre for Emotional Health, Department of Psychology, Macquarie University bertujuan mengukur stres dalam bentuk positif dan negatif berdasarkan persepsi dan jawapan responden. CASE sesuai diaplikasikan kepada kanak-kanak sekolah berumur 6 hingga 17 tahun (Bedell, 2011). Instrumen CASE telah diguna pakai oleh ramai penyelidik antarabangsa seperti Allen dan Rapee (2009), Sandberg, Allen dan Rapee (2012) dan Charities (2016). Instrumen tersebut juga telah menyediakan jadual petunjuk bagi setiap tahap skor, berdasarkan jadual 1 berikut: 
Jadual 1: Penilaian Stres CASE 1.1.

\begin{tabular}{|c|l|}
\hline Total & Tahap \\
\hline $0-40$ & -Tahap stres rendah- kanak-kanak dapat mengendalikan stres \\
\hline $41-70$ & $\begin{array}{l}\text {-Tahap stres serdahana- terdapat banyak perkara yang berlaku dalam } \\
\text { kehidupan kanak-kanak, tetapi ianya dapat dikendalikan dengan baik }\end{array}$ \\
\hline $71-90$ & $\begin{array}{l}\text {-Tahap stres serdahana tetapi sedang meningkat. } \\
\text { - terdapat banyak perkara yang berlaku dalam kehidupan kanak-kanak, } \\
\text { tetapi ianya dapat dikendalikan dengan baik }\end{array}$ \\
\hline $91-120$ & $\begin{array}{l}\text {-Tahap serdahana tetapi meningkat tinggi- Stres sedang meningkat } \\
\text { Sumber: Child Adolescent Survey of Experiences(CASE):Charities (2016) }\end{array}$ \\
\hline
\end{tabular}

\section{DAPATAN KAJIAN}

Berdasarkan objektif kajian, terdapat dua persoalan utama yang harus dijawab, iaitu sama ada kanak-kanak prasekolah orang asli mengalami stres dan mengenal pasti simptom stres yang ditunjukkan.

Daripada ujian pengukuran stres CASE yang telah dijalankan oleh guru kelas dan diselia oleh guru Penolong Kanan Hal Ehwal Murid (PKHEM), mendapati kanak-kanak orang asli kaum Senoi telah mengalami stres. Catatan hasil dari ujian stres CASE menunjukkan kanak-kanak tersebut mengalami stres di tahap skor 75 mata bagi keseluruhan penilaian tersebut. Berdasarkan huraian petunjuk skala CASE bagi capaian nilai skor antara 71 hingga 90 mata menunjukkan bahawa kanak-kanak prasekolah orang asli yang terlibat dalam kajian mengalami tahap pengaruh stres di tahap serdahana tetapi sedang meningkat tinggi. Skala tersebut juga menguraikan bahawa terdapat banyak perkara yang berlaku dalam kehidupan kanak-kanak terbabit. Walau pun petunjuk skala menyatakan bahawa kanak-kanak yang berhadapan dengan stres dalam lingkungan paras 71 hingga 90 dapat mengendalikan dengan baik, namun skala tersebut juga menyarankan agar usaha segera dilakukan bagi membantu kanak-kanak tersebut mengatasi sumber stres.

Berdasarkan data yang telah diperoleh dari skala pengukuran stres CASE, kajian telah diteruskan lagi untuk mengenal pasti simptom stres. Dapatan kajian menunjukkan simptom stres yang telah di kenal pasti adalah simptom Onychophagia. Onychophagia adalah habit menggigit kuku dan ia merupakan masalah psiko-emosi (psycho emotional) berkait dengan stres (Sachan dan Chaturvedi, 2012).

Dalam kajian yang dijalankan mendapati simptom Onychophagia telah ditunjukkan oleh kanak-kanak tersebut sewaktu berhadapan dengan stres. Menurut Siddiqui, Qureshi, Marei, dan Mahfouz (2017), Onychophagia adalah satu simptom yang ditunjukkan oleh kanakkanak atau remaja sewaktu mengalami stres. Ciri-ciri Onychophagia adalah menggigit kuku, menghisap ibu jari, atau sebagainya sewaktu mengalami stres. Mereka biasanya melakukan sedemikian apabila berhadapan dengan stres, bosan, bimbang atau lapar. Kesemua situasi yang dinyatakan tersebut adalah fenomena yang sama antara mereka iaitu wujud perasaan tidak tenteram. Ianya adalah habit yang menggambarkan tingkah laku yang berhadapan dengan 
tekanan (stres). Tingkah laku tersebut biasanya berlaku secara spontan atau tingkah laku automatik (an automatic behaviour) (Pacan, Grzesiak, Reich, Kantorska-Janiec dan Szepietowski, 2014).

Masalah Onychophagia biasanya akan bermula dalam lingkungan umur 3 atau 4 tahun dan berkemungkinan boleh perlanjutan hingga kepada peringkat remaja dan dewasa. (Siddiqui, Qureshi, Marei dan Mahfouz, 2017).

Onychophagia adalah tindakan menggigit hujung kuku atau kulit lembut (soft tissue) yang terdapat di sekeliling kuku. Menurut Siddiqui, Qureshi, Marei, dan Mahfouz (2017) menggigit kuku adalah habit yang menggambarkan tingkah laku yang berhadapan dengan stres. Sachan dan Chaturvedi (2012) memperjelaskan bahawa habit menggigit kuku merupakan masalah psiko-emosi (psycho emotional) berkait dengan anxiety dan stres. Mereka biasanya melakukan sedemikian apabila berada dalam keadaan tertekan, iaitu wujud perasaan tidak tenteram.

Dalam kajian ini simptom Onychophagia yang ditunjukkan oleh kanak-kanak orang asli kadang kala turut disertakan dengan tindakan memintal hujung baju. Walau bagaimana pun, tindakan menggigit kuku adalah lebih dominan dilakukan oleh kanak-kanak terbabit berbanding dengan memintal hujung baju.

Tingkah laku tersebut dapat dikenal pasti melalui pemerhatian yang dijalankan oleh penyelidik. Berdasarkan pemerhatian, didapati kanak-kanak tersebut telah menggigit kuku sewaktu berada dalam barisan untuk menunggu giliran bagi sesi soal jawab dengan guru berkaitan isi pelajaran. Rutin habit tersebut dapat dikenal pasti melalui pemerhatian yang dilakukan dalam pelbagai ruang masa yang berbeza seperti di awal, pertengahan atau di hujung sesi pembelajaran selama tiga minggu yang berlainan. Penyelidik telah memerhati dan merakam tingkah laku Onychophagia yang dilakukan oleh kanak-kanak tersebut. Dalam pemerhatian tersebut, penyelidik telah dapat mengenal pasti tingkah laku memintal atau menggenggam hujung dalam persekitaran sebenar.

Selain dari pemerhatian, dapatan dikukuhkan lagi dengan pengesahan guru dan PM sebagai informan. Berdasarkan temu bual yang telah di jalankan terhadap dua orang individu yang paling hampir dengan kanak-kanak terbabit. Mereka mengakui bahawa kanak-kanak terbabit sememangnya kerap melakukan tindakan menggigit kuku. Keadaan tersebut adakalanya berlaku sewaktu kanak-kanak terbabit berseorangan, namun kerap kali dapat dilihat kanak-kanak tersebut melakukan tindakan menggigit kuku sewaktu berada dalam barisan atau sewaktu sesi soal jawab. Hal ini berdasarkan perakuan dan pemerhatian guru; "...dia mesti gigit kuku kalau kita suruh dia bangun, suruh dia membaca...”. Guru juga menjelaskan bahawa tindakan menggigit kuku yang dilakukan oleh responden memberi impak kepada kesihatan tangan dan jarinya.

Kenyataan tersebut terbukti berdasarkan pemerhatian dan pemeriksaan yang dilakukan oleh penyelidik mendapati terdapat kesan kerosakan kepada kuku dan tisu lembut di hujung jari kanak-kanak terbabit. Berdasarkan pemeriksaan pada hujung jari dan kuku, didapati terdapat kesan kerosakan pada struktur kuku dan keseragaman bentuk kuku. Bahagian tisu lembut di hujung dan kiri kanan setiap jari kanak-kanak terbabit kelihatan telah rosak dan terdapat kesan kulit yang telah tertanggal dan menipis. Menurut guru, perlakuan menggigit kuku oleh kanak-kanak terbabit telah lama disedari oleh beliau. Tindakan seperti menegur atau mengetuk tangan dengan pembaris (secara perlahan) adalah tindakan yang telah dilakukan bagi mengekang perlakuan menggigit kuku. Kesan dari hukuman yang dilakukan telah 
menampakkan sedikit hasil dalam pengurangan kadar kekerapan menggigit kuku “...selalu kena ketuk tangan tu, baru kurang sikit..." seperti yang dinyatakan oleh guru beliau.

Malah perkara tersebut juga diakui oleh PM bahawa tindakan menggigit kuku yang dilakukan oleh kanak-kanak terbabit menjurus kepada tindakan mencederakan ini. Hal ini kerana, terdapat kesan luka dan tisu yang terkoyak di hujung jari kanak-kanak terbabit “...kadang kadang nampak kulit dia terkopek, pedih la tu..kalau teruk sangat kita tampal plaster". Kecederaan tersebut memberi kesan kesihatan kanak-kanak terbabit dan beliau sering mengadu tentang kesakitan (pedih) di hujung jari apabila diarah membasuh tangan sewaktu hendak makan di waktu rehat "...bila basuh tangan nak makan, mula la pedih katanya”.

Namun keadaan tersebut berbeza sewaktu berada di rumah. Hal ini berdasarkan hasil temu bual yang dijalankan bersama ibu bapa kanak-kanak terbabit. Dalam soalan yang diajukan sewaktu sesi temu bual bersama ibu bapa kanak-kanak terbabit, mereka sepakat mengatakan 'tidak' terhadap perlakuan menggigit kuku yang mungkin ada dilakukan oleh kanak-kanak terbabit sewaktu berada di rumah. Menurut mereka, tidak terdapat sebarang habit atau perlakuan yang pelik atau luar biasa seperti tindakan menggigit kuku atau memintal hujung baju yang dapat dilihat dari perlakuan anak mereka. Hal ini menunjukkan bahawa tindakan menggigit kuku hanya dilakukan oleh kanak-kanak tersebut sewaktu berada di sekolah sahaja.

\section{Perbincangan}

Onychophagia didefinisikan sebagai tingkah laku (habit) menggigit kuku. (Sachan dan Chaturvedi, 2012). Simptom Onychophagia biasanya bermula dari zaman kanak-kanak 1 hingga 3 tahun dan diklafikasikan sebagai himpunan masalah (group of disorders) tingkah laku dan emosi yang spesifik yang biasanya terjadi di zaman kanak-kanak dan remaja (Pacan,Grzesiak, Reich, Kantorska-Janiec dan Szepietowski, 2014). Masalah tingkah laku Onychophagia, adalah suatu simptom stres yang berkait kuat dengan masalah psiko-emosi (psycho emotional). Individu yang mengalami Onychophagia biasanya akan menggigit hujung kuku atau kulit lembut (soft tissue) yang terdapat di sekeliling kuku dan adakalanya disertakan dengan tingkah laku sampingan seperti masturbasi, dan nose picking (Sachan dan Chaturvedi, 2012).

Ianya berpunca dari perasaan kebosanan (boredom), anxiety dan nervousness. Masalah Onychophagia harus segera diambil perhatian dan ditangani dengan berkesan kerana masalah ini membawa impak negative yang pelbagai. Menurut Siddiqui, Qureshi, Marei dan Mahfouz (2017), tingkah laku Onychophagia berkait dengan sikap agresif (aggression), gangguan kawalan impulse (an impulse control disorder) dan tindakan mencederakan diri sendiri (selfmutilation behaviour). Hal ini terbukti berdasarkan dapatan kajian yang menunjukkan terdapat tingkah laku mencederakan diri merujuk kepada tindakan menggigit tisu kulit lembut di sekitar kuku sehingga mengakibatkan luka. Keadaan tersebut boleh menjadi lebih parah apabila berlakunya jangkitan kuman terhadap luka tersebut.

Oleh itu, tingkah laku Onychophagia harus segera ditangani dan dikawal bagi membendung penularannya dalam tempoh masa yang singkat. Masalah tersebut sekiranya tidak dikawal atau dirawat akan memberi kesan terhadap perkembangan kanak-kanak tersebut sehingga dewasa. Hal ini terbukti berdasarkan kajian yang dijalankan oleh Siddiqui, Qureshi, Marei dan Mahfouz (2017) mendapati hampir 28 peratus hingga 33 peratus kanak-kanak antara umur 7 hingga 10 tahun mengalami Onychophagia dan mencapai 44 peratus bagi remaja yang mengalami simptom tersebut. Dapatan kajian yang telah dijalankan juga mendapati sekitar 19 peratus hingga 29 peratus golongan awal dewasa menghadapi masalah Onychophagia. 
Dari sudut psikologi, tingkah laku menggigit kuku yang dilakukan oleh kanak-kanak tersebut merupakan tingkah laku automatik (an automatic behaviour) sebagai salah satu strategi daya tindak (coping skills) yang berlaku sewaktu berhadapan dengan stres. Hal ini kerana tindakan menggigit kuku atau onychophagia adalah salah satu cara perlegaan stres yang biasa di lakukan oleh individu yang berada dalam keadaan tertekan (Sachan dan Chaturvedi, 2012). Perkara tersebut terbukti berdasarkan kajian yang dijalankan oleh (Pacan, Grzesiak, Reich, Kantorska-Janiec dan Szepietowski, 2014) yang menunjukkan tahap tekanan (tension) sebelum menggigit kuku adalah sebanyak 65.7 peratus, dan menurun kepada perasaan yang melegakan (feelings of pleasure) selepas menggigit kuku adalah 42 peratus (Pacan, Grzesiak, Reich, Kantorska-Janiec dan Szepietowski, 2014). Keadaan tersebut terbukti berdasarkan tingkah laku kanak-kanak terbabit yang hanya berkelakuan menggigit kuku apabila berhadapan dengan stres sewaktu di sekolah, dan perkara tersebut tidak berlaku di rumah dalam persekitaran yang dirasakan selamat.

\section{KESIMPULAN}

Ternyata masalah tingkah laku Onychophagia harus diambil perhatian. Hal ini kerana kebanyakan guru atau pihak sekolah tidak menyedari tentang wujudnya sindrom tersebut. Seringkali masalah tingkah laku Onychophagia dianggap sebagai suatu masalah yang terpencil. Namun hakikatnya ianya adalah sindrom yang besar yang memberi kesan kepada perkembangan kanak-kanak prasekolah. Berdasarkan laporan kajian Pacan, Grzesiak, Reich, Kantorska-Janiec dan Szepietowski (2014), dianggarkan lebih dari separuh dari populasi umur persekolahan kerap, atau biasanya menghadapi habit tersebut dan hampir 19 peratus hingga 29 peratus masalah ini akan berlanjutan hingga ke alam dewasa (Siddiqui, Qureshi, Marei dan Mahfouz, 2017). Oleh itu, usaha proaktif secara kolektif perlu diambil oleh semua pihak bagi membantu kanak-kanak prasekolah orang asli berhadapan dengan stres bagi menyokong perkembangan dan potensi mereka di masa depan.

\section{RUJUKAN}

Allen, L. J. \& Rapee, R. M. (2009). Are report differences in life events for anxious children and controls due to comorbid disorders? Journal of Anxiety Disorders. vol. 23 (4).51-68.

Armstrong, S. \& Buckley, B. (2011). An investigation into the attendance and retention of aboriginal and Torres Strait Islander students: Research and theory about what works. Australian: Australian Council for Educational Research (ACER).

Bedell, G. (2011). The child and adolescent scale of environment (CASE). USA: Tufts University.

Bourke, J. C. (2000). Better practice in school attendance improving the school attendance of indigenous students. Australia: Commonwealth Department of Education Training and Youth Affairs.

Braun, V. \& Clarke, V. (2013). Successful qualitative research. London: SAGE Publications.

Carter, R. T. (2007). Assessing race-based traumatic stress racism and psychological and emotional injury: Recognizing. The Counseling Psychologist.vol.35. (1). 93-105.

Charities, C. (2016). Helping children manage stress. Retrieved from catholic charities:www.catholiccharitiesmd.org/children-and-families/pdfs-families/ helping-children-manage-stress-1.pdf

Chuan Yan Piaw. (2006). Kaedah penyelidikan. Kuala Lumpur: McGraw Hill.

Clark, 1. P and Creswell, J. W. (2015). Understanding research. New Jersey: Pearson Education.

Cohen, L., Manion, L. \& Morrison, K. (2007). Research methods in education. London and New York: Routledge Group.

Creswell, J. W. (2005). Educational research: Planning, conducting and evaluating qualitative \& quantitative. New Jersey: Pearson Education.

Creswell, J. W. (2013). Qualitative inquiry \& research design. Thousand Oaks, California: SAGE Publications 
Deborah, A. A, Philip J. S., Geoffrey K. P. Sparling, Chelsea, J. R. B and Alex, B.D.H.(2013). Urban aboriginal and Torres Straiy Islander children's exposure to stressful events. Medical Journal of Australia. vol.199 (1), 42-45.

Fariza Md. Sham. (2005). Tekanan emosi remaja Islam. Bangi: Universiti Kebangsaan Malaysia.

Fraenkel, J.R. \& Wallen, N.E. (2000). How to design \& evaluate research in education. Boston: McGraw Hill. (Paradise, 2004);

Kementerian Pendidikan Malaysia. (2011). Garis panduan perlaksanaan minda sihat menangani tekanan emosi (stres) dalam kalangan murid sekolah di Malaysia. Putrajaya: Kementerian Pendidikan Malaysia.

Kementerian Pendidikan Malaysia. (2011). Pendidikan awal kanak-kanak. Cyberjaya: Institut Pendidikan Guru.

Kementerian Pendidikan Malaysia. (2014). Garis Panduan perlaksanaan minda sihat menangani tekanan (stres) dalam kalangan murid di sekolah. Putra Jaya: Kementerian Pendidikan Malaysia.

Lee Lam Thye. (2018). Segerakan perlaksanaan Pelan Strategik Kesihatan Mental Negara. Kuala Lumpur: Utusan Malaysia.

Marcelo, A., K. and Yates, T. M. (2014). Prospective relations among preschooler's play, coping, and adjustment as moderated by stressful events. Journal of Applied Development Psychology. xxx. 1-11.

Mazlan Lazim. (2015, 10 15). Kisah sebenar trajedi kehilangan murid orang asli. Retrieved from BHonline: www.bharian.com.my

McRae, D. (2008). Student engagement: Attendance, participation and belonging. Australia: Department of Education, Science and Traning.

Morbiditi dan Kesihatan Kebangsaan (NHMS). (2016). Gejala sakit mental pelajar boleh cetus masalah kronik. Kuala Lumpur: Unit Komunikasi Koperat, Berita Harian.

Nik Nasaruddin Nik Leh. (2015, Okt 10). 2 Kanak-kanak orang asli kekurangan zat yang serius. Retrieved from Berita Nasional BHonline: www.bharian.com.my

Nor Aimi Harun. (2011). Fenomena stres dalam kalangan kanak-kanak berbakat. Tanjung Malim: Universiti Pendidikan Sultan Idris.

Norly Jamil. (2010). Tingkah laku emosi kanak-kanak dan ekspresi emosi ibubapa. Proceedings of The 4th International Conference on Teacher Education: Join Conference UPI \& UPSI (pp. 1-11). Bandung, Indonesia: UPSI.

Nur Bahiyah, Maryati, Azman dan mohd Najib. (2013). Penerapan elemen sekolah rimba Malaysia dalam kalangan murid orang asli. 2nd International Seminar on Quality and Affordable Education (ISQAE 2013) (pp. 424-432). Johor Bahru: Falcuty of Education. UTM.

O'Leary, Z. (2004). The Essential Guide to doing research. London: SAGE Publications.

Pacan, P., Grzesiak M., Reich, A., Kantorska-Janiec, M., and Szepietowski, J.C. (2014). Onychophagia and Onychotillomania: Prevalence, Clinical Picture and Comorbidities. Acta Derm Venereol 2014.Vol. 94. 67-71

Patton, M. Q. (1990). Qualitative evoluation and research methods. Newbury Park London: Sage Publications.

Patton, M. Q. (2002). Qualitative research \& evaluation mathods. Thousand Oaks: Sage Publications.

Purdie, Nola, Buckley \& Sarah. (2010). School attendance and retention of indigenous Australian students. Australia: Australia Institut of Health and Welfare.

Puvarasi Elamurugan. (2013). Hubungan stres dengan personaliti tingkahlaku devian dan daya coping di kalangan pelajar sekolah menengah daerah Johor Baharu. Skudai: Universiti Teknologi Malaysia.

Sachan, A., Chaturvedi TP. (2012). Onychophagia (nail biting), anxiety, and malocclusion. Indian Journal of Dental Research. Vol.23. (5). 680-682

Sandberg, S., Allen, J. L. \& Rapee, R. M. (2012). Assessment of Maternally Reported life eventsin children and adolescents: A comparison of interviewand checklist methods. Journal of Psychopathology and Beharvioral Assessment. vol. 34, 204-215.

Siddiqui J.A., Qureshi S.F., Marei W.M., Mahfouz T.A. (2017). Onychophagia (Nail Biting): A Body Focused Repetitive Behavior due to Psychiatric Co-morbidity. Journal of Mood Disorders (JMOOD) 2017. Vol.7 (1).9-47.

Utusan Malaysia. (2011). Atasi masalah keciciran orang asli. Kuala Lumpur: Utusan Publications.

Videbeck, S. L. (2011). Psychiatric-mental health nursing: fifth edition. China: Wohers Klower Health I Lippincott \& Wilkins. 